\title{
Citrus in Benin Republic: past, present, and future challenges
}

\author{
Fabrice Afloukou ${ }^{1,2}$, Valerien Zinsou ${ }^{2} \&$ Nuket Onelge $^{1}$
}

\section{SUMMARY}

Citrus is a magnificent crop fruit globally known for its nutritional, industrial and medical properties. The crop is characterized by an abundant yield and is then a consistent cash provider around the world. Unfortunately, the crop fruit has been facing increasing biotic, abiotic and technical constraints in Benin Republic. Citrus production is in jeopardy in the country. This situation may turn into a nightmare if no actions are undertaken to mitigate those constraints. This paper provides an overview of the past and current research and knowledge linked to citrus production in the Benin Republic in order to point out gaps that should be filling-up for its sustainable production. It also intends to stimulate future research activities for better citrus production.

Index terms: abiotic constraints, climate change, diseases, pests, and yield.

\section{Citrus em Benin: passado, presente e desafios futuros}

\section{RESUMO}

Os citros são frutas magníficas e conhecidas em todo o mundo por suas propriedades nutricionais, industriais e medicinais. A produção de citros é caracterizada como abundante em todo o mundo, portanto, é uma fonte consistente de divisas internacionalmente. Infelizmente, a produção de citros enfrenta restrições bióticas, abióticas e de manejo, crescentes em Benin. A produção de citros está em risco no país. Essa situação pode se transformar em um pesadelo se nenhuma ação for realizada para mitigar suas restrições. Este artigo oferece uma visão geral das pesquisas anteriores e atuais e do conhecimento vinculado à citricultura em Benin, a fim de apontar lacunas que devem ser preenchidas para sua produção sustentável. Também visa estimular futuras atividades de pesquisa para uma melhor produção de citros.

Termos de indexação: restrições abióticas, mudanças climáticas, doenças, pragas e produtividade.

\footnotetext{
${ }^{1}$ Laboratory of Citrus Virology, Department of Plant Protection, Faculty of Agriculture, University of Çukurova, Adana, Turkey

${ }^{2}$ Laboratoire de Phytotechnie, d'Amélioration et de Protection des Plantes - LaPAPP, Faculty of Agronomy - FA, University of Parakou, Parakou, Benin Republic

Corresponding author: Fabrice Afloukou, Laboratory of Citrus Virology, Department of Plant Protection, Faculty of Agriculture, University of Çukurova, 01330, Sariçam, Adana, Turkey. E-mail: afloukoufm@yahoo.com
} 


\section{INTRODUCTION}

Member of the largest genus in the Rutaceae family, Citrus, also known as agrume (sour fruits), is the most produced and consumed fruit in the world, contributing to human diets (Liu et al., 2012). The citrus fruits are rich in fibre, vitamins, minerals, phytochemicals, limonoids, and flavonoids (Turner \& Burri, 2013).

Citrus is grown in the «Citrus belt» ranging from tropical to semi-tropical and subtropical regions of the globe between $40^{\circ} \mathrm{N}$ and $40^{\circ} \mathrm{S}$ latitudes in more than 140 countries (Krueger, 2003; Ollitrault \& Navarro, 2012). In 2017, more than 146 million metric tons of citrus fruits were harvested on a little less than 9.3 million hectares. The bulk of the production is concentrated in the northern hemisphere. Africa provides $13.42 \%$ of the global production with Egypt, Nigeria, SouthAfrica, Morocco, and Algeria as leading countries (FAO, 2018).

Regarding local soils and climates, the southern Benin Republic is more suitable for the crop fruit production. That encouraged leaders to import worldwide recognized citrus cultivars and undertook intensive citrus cultivation in the 1960s. In contrast to developed countries, it is not easier to access recent data, particularly on citrus in some African countries, including the Benin Republic, where the production dropped over the years. This is a major obstacle to national and regional scientists, policy makers, extension personnel and other stakeholders. For these reasons we compiled this review on the history, the current status of citrus cultivation, perspectives for the development of the Beninese citrus industry.

\section{CULTIVARS AND ROOTSTOCKS}

Citrus was domesticated in south-eastern-Asia more than 4000 years ago and spread around the world. Although a few genera (Clementine mandarin, Egyptian lime, South African Rough lemon) originated in Africa, citrus was first introduced to the continent through northern and eastern-Africa by Arab and Indian traders. Portuguese introduced citrus into West-Africa (Kruger, 2003), but the first introduction to Benin Republic is still unknown.

Modern and intensive citrus culture began in Dahomey (Now Benin Republic) by large-scale advocacy of I.F.A.C (Institut des Fruits et Agrumes Coloniaux) and the establishment of SoNaFeL (Société Nationale des Fruits et Légumes) by the Benino-Israeli cooperation in the 1960s. Citrus collections (Toué/Bohicon district, Sékou/Allada district, Allahè/Za-kpota district), wood park (Toué/Bohicon district), rootstock trial (Allahè/Za-kpota district) and nurseries (Allahe/Za-kpota district, Togba/ Abomey-Calavi district and Djassin/Porto-Novo district) were implemented (Montagut, 1974).

Mexican acid lime (C. aurantifolia (Christm.) Swingle); Tahiti acid lime (C. latifolia Tanaka); Rangpur lime (C. limonia); Eureka and Lisbon lemon (C. limon); Rough lemon (C. jambhiri Lush 'Rangpur'); Volkamer lemon (C. volkameriana Ten. and Pasq.); Hamlin, Pineapple, Valencia late, Olinda Valencia, Campbell Valencia, Frost Valencia, Parson Brown, Trovita, Washington Navel sweet orange (C. sinensis (L.) Obseck); Cleopatra mandarin (C. reshni Hort.ex Tan); Clementine mandarin (Citrus clementina Hort. Ex Tan); King mandarin (C. nobilis var King); Kara mandarin (King tangor x Owari satsuma); Fremont mandarin (Clementine mandarin x Ponkan mandarin); Satsuma mandarin (C. unshiu Marcovitch); Carval Hal', Common, Malvasi, Murcott, and Ponkan mandarin (C. reticulata Blanco); Dancy and Beauty tangerine (C. reticulata Blanco); Minneola, Orlando and Wekiwa tangelo (C. reticulata x C. paradisi); Fairchild, Nova, Lee, Osceola, Page, and Robinson tangelo (Orlando tangelo x Clementine mandarin); Bali, Shambar, Star Ruby, Marsh, Redblush, Duncan grapefruit (C. paradisi Macf.); Temple and Ortanique tangor (Tangerine $\mathrm{x}$ Sweet orange); Common sour orange and Bouquetier de Nice sour orange (C. aurantium L.); Troyer citrange (C. sinensis Osbeck $\times$ Poncirus trifoliata Raf.), Bergamot (C. Bergamia Risso), Alemow (C. macrophylla Wester), and Nanshodaidai (C. taiwanica Tan. Shim.) were imported from I.F.A.C Foulaya (Guinea), USA, France, Israel,and Nigeria between 1961 and 1972 (Cassin, 1974; Montagut, 1974; Praloran, 1972; Vogel, 1972, 1975).

Pests, diseases, non-adaptation to local climates, and low fruit quality issues forced to stop the extension of some of them in 1974 (Cassin, 1974; Vogel, 1975). Currently, Hamlin, Lisa, Pineapple, and Valencia late sweet orange; Eureka and Lisbon lemon; Tahiti acid lime and Kaffir lime (C. hystrix); Minneola and Orlando tangelo; Ortanique tangor and Dancy tangerine grafted most of the time on Rangpur lime are the most popular and grown cultivars (Akohoue et al., 2018; Lokossou et al., 2009; Massokonon, 2015). 


\section{CLIMATE}

Citrus grows in tropical, subtropical, and semitropical regions. The crop requires a temperature between $21^{\circ} \mathrm{C}$ and $30{ }^{\circ} \mathrm{C}$ for its optimal physiological activities; temperature higher than $35{ }^{\circ} \mathrm{C}$ and lower than $13{ }^{\circ} \mathrm{C}$ damage the physiological activities while $-7^{\circ} \mathrm{C}$ is lethal (Cirad, 2016). The water requirement varies a lot with the seasons, plant stage and age, cultivars, and climatic conditions. It is admitted that 40-45 inch (1016-1143 mm) per annum is sufficient for citrus cultivation (Retiz, 1968).

As described by Boko (1992), the Benin Republic has three (3) climatic zone, namely sudanian, sudano-guinean, and guinean zone (Figure 1):

- Sudanian zone:It is located in the north of $10^{\circ} \mathrm{N}$, and is characterized by $950-1300 \mathrm{~mm}$ of rainfall per annum. The rainy season ranges from april to november with august as the rainiest month. Annual average temperature, relative humidity, day length, and wind speed are $17-33^{\circ} \mathrm{C}, 20-47 \%, 2862$ hours, and 1.8-5.4 $\mathrm{m} / \mathrm{s}$, respectively;

- Sudano-guinean zone: located in the centre of the country (from $7^{\circ}$ to $10^{\circ}$ North), it owns $1,200 \mathrm{~mm}$ of rainfall; average temperature of $22.5-35.2{ }^{\circ} \mathrm{C}$; a relative humidity of $30-83 \%$; a day length of 2305 hours and a mean wind speed of $0.3-2.2 \mathrm{~m} / \mathrm{s}$. Two rainy seasons (from march-july and september-november) and two drying seasons (during august and from decemberfebruary) are available;

- Guinean zone: found in the south (between $6^{\circ} 30$ and $7^{\circ}$ North), it shows a West-East gradient from $950 \mathrm{~mm}$ at Grand-Popo (in the West) to $1,500 \mathrm{~mm}$ of rainfall per annum at Kétou (in the East). Annual average temperature, relative humidity, day length and mean wind speed are $24-31{ }^{\circ} \mathrm{C}, 58-95 \%, 2862$ hours, and 2.5-4.2 m/s, respectively. Two rainy and dry seasons are also available in this zone. The first rainy season covers march or april to july with 40 to $60 \%$ of the annual rainfall while the second rainy season range from september to november except the South-east where it covers september to october with 18 to $30 \%$ of annual rainfall.

Considering the soils, climate parameters, and the relative distribution of rainfall, the guinean zone is the most suitable for citrus cultivation in the Benin Republic. That is probably the reason why nearly all of the citrus orchards are located in this zone.

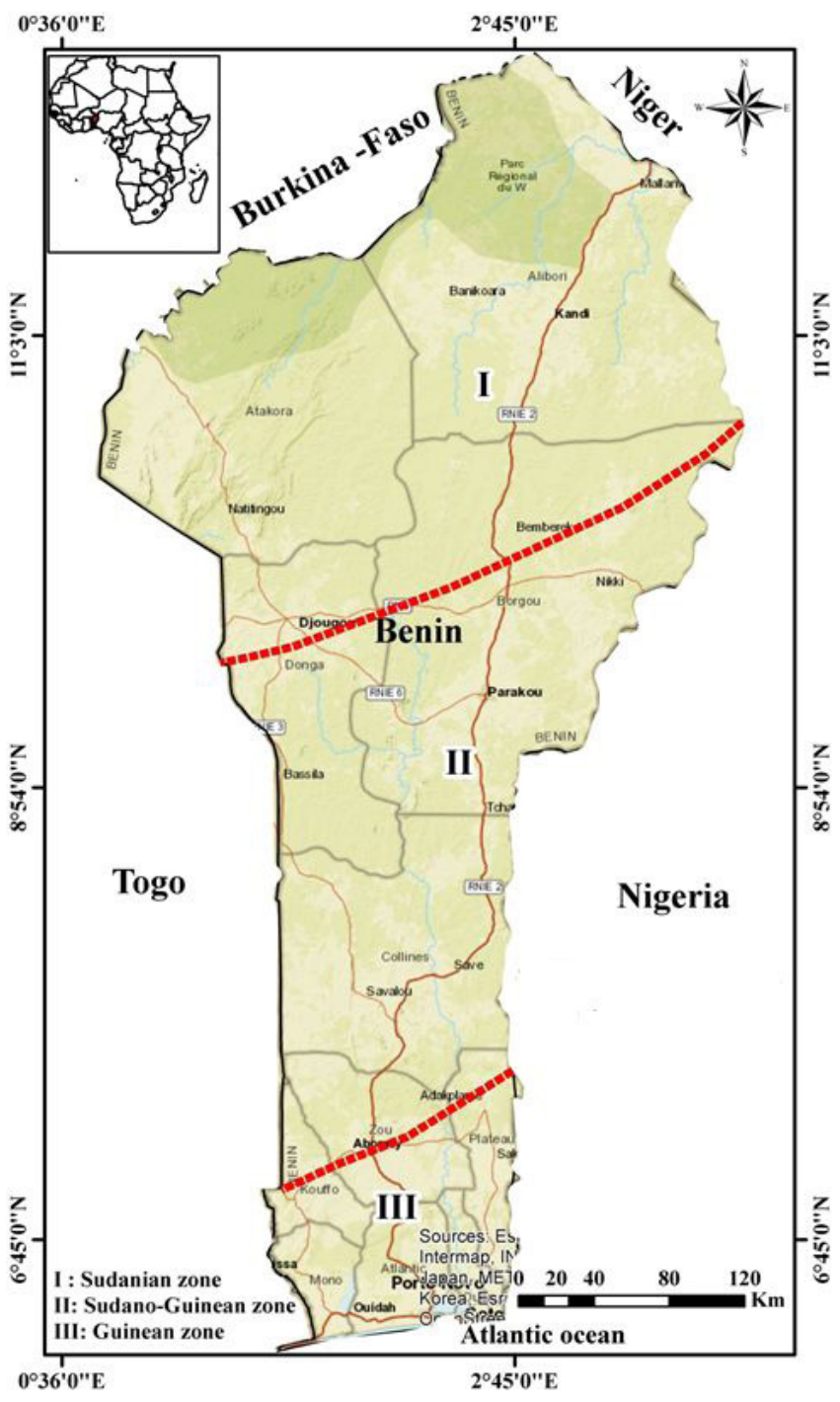

Figure 1. Climatic zones of Benin Republic.

\section{PRODUCTION}

Citrus is the second grown and traded crop fruit after pineapple (Ananas comosus) in Benin Republic (Tossou et al., 2012). The crop grows substantially in the whole country but commercial orchards are located in the southern-Benin Republic with Zou as the most relevant and leading department (Figure 2) (Gnimadi, 2008; Praloran, 1972).

Sweet orange is the main grown cultivar with Valencia and Pineapple orange the overlooking (Akohoue et al., 2018). The sweet orange harvested area increases over the years from 1,410 ha in 1961 to 6,375 ha in 2017 while the yield decreased from 7,262.4 $\mathrm{kg} \mathrm{ha}^{-1}$ in 1961 to $2,317.4 \mathrm{~kg} \mathrm{ha}^{-1}$ in 2017 (Figure 3) (FAO, 2018). Citrus tends towards 


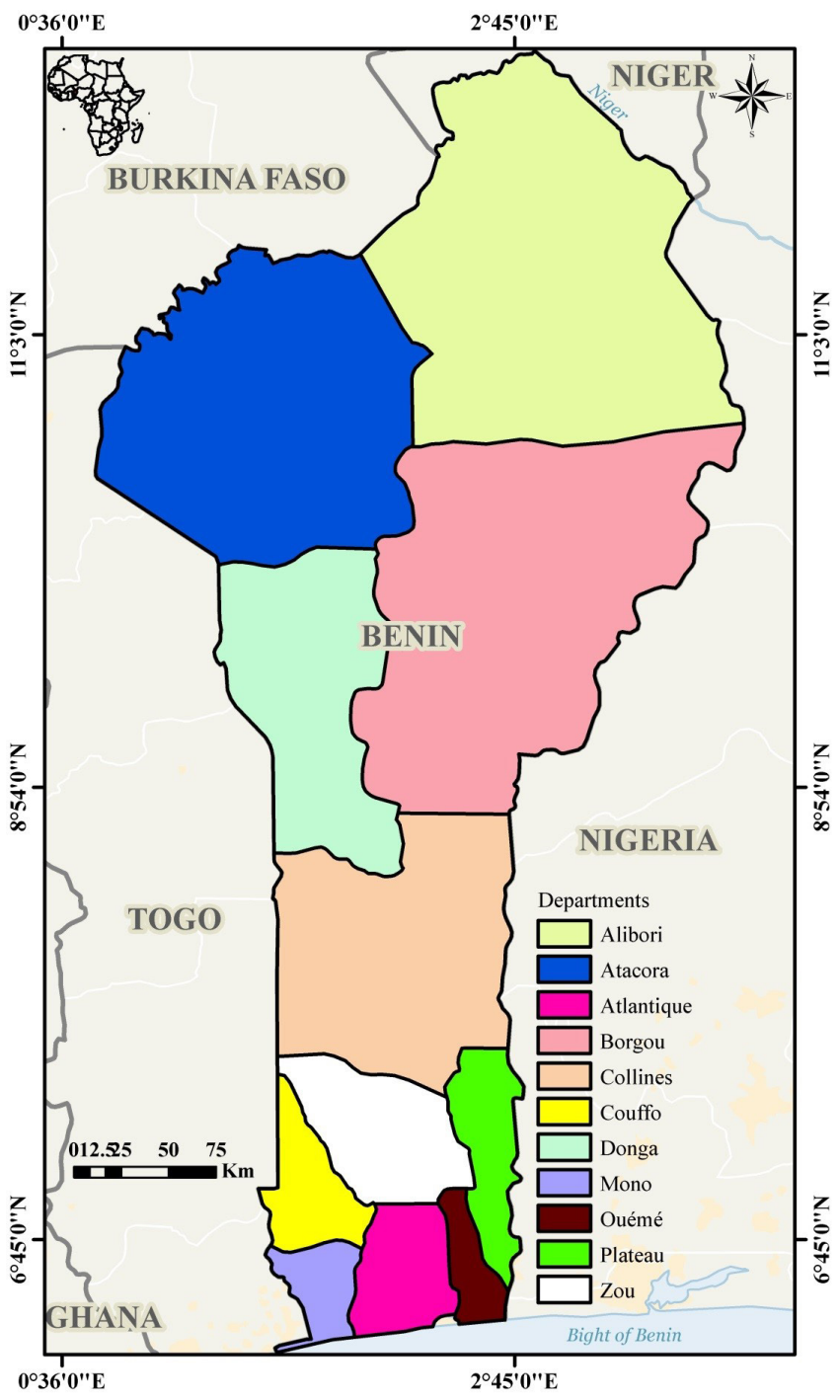

Figure 2. Departments of Benin Republic. extensive production instead of an intensive one. In the second half of the decade 1980 s, there was a renewal of orange orchards coupled with new cultivars' introduction. That was an utter fiasco as orange yield has started a long and massive decrease since 1991, leading to the second -lowest sweet oranges yield (2,308 kg ha-1) ever recorded in Africa, in 2017. These trends are in accordance with the mismanagement of nurseries and orchards.

Indeed, until the 1970s, both I.F.A.C and SoNaFeL owned modern nurseries with well-trained men. The cut-off of the diplomatic relationship between the "Popular Republic of Benin" (Current Benin Republic) and Israel in 1973 (Levy, 2008), coupled with the economic issues of the decade 1980s enjoined the government to close SoNaFeL in 1986. Since then, citrus nursery workers and farmers lack training and supports. Currently, most actors do not know about citrus diseases and sanitation rules. In the departments of Mono and Couffo (Figure 2) for instance, sweet orange plantlets are not grafted, delaying the first flowering period (7-10 years after planting date) and exposing trees to citrus foot rot disease (Lokossou et al., 2009).

Having regards to the rest of the southern-Benin Republic, the nurseries are directly made on the ground using seeds from informal origins. The rootstocks are kept on the ground until 8-9 months old when a stem diameter of nearly $1 \mathrm{~cm}$ is achieved; the scions are grafted on it at around $30 \mathrm{~cm}$ above collar using the T-budding method (Massokonon, 2015). The closeness of the scions to the soil chiefly observed in Zou and Atlantique departments (Figure 3) (Lokossou et al., 2009) exposes those scions to citrus foot rot disease. The grafted plants are transferred

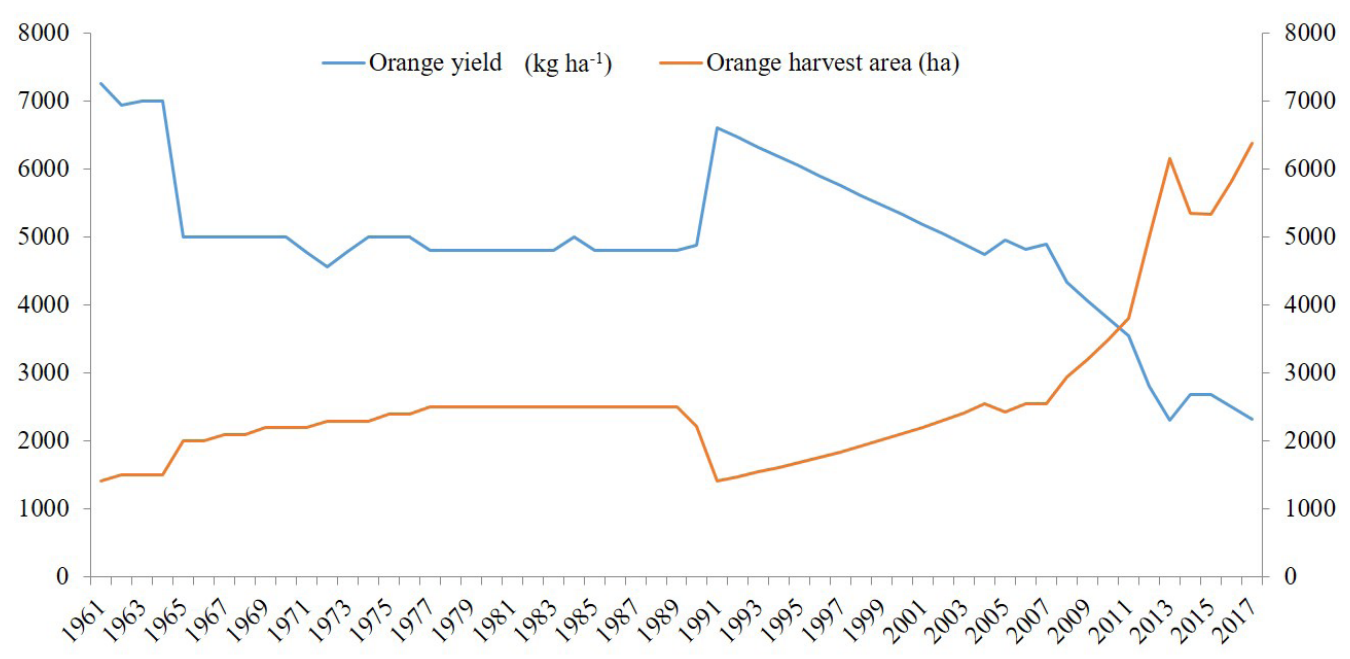

Figure 3. The sweet orange yield and harvested area in Benin Republic from 1961 to 2017. Source: FAO (2018). 
to plastic pots where they stay until been purchased by farmers. Later, the grafted citrus are transferred to the open field (rainfall- dependent) at the rate of 260 to 271 trees per hectare (Akohoue et al., 2018). In hot and humid areas like the Benin Republic, priority should be given to a planting rate ranging from 156 to 204 plants. ha $^{-1}(8 \mathrm{~m} \times 8 \mathrm{~m}, 7 \mathrm{~m} \times 7.5 \mathrm{~m}, 7 \mathrm{~m} \times 7 \mathrm{~m})$ so as to ease air circulation in orchards, lower as much as possible the accumulation of moisture on leaves, and avoid strong growth in height. The first blooming occurs 3-4 years after the transfer date according to the cultivars.

The citrus fruits are harvested twice a year: march-july and november-january. The harvested fruits are stored and transported in polyethylene bags or bulk. Wholesalers exhibit them in local basket or in a stack on the ground, a potential source of post-harvest pathogens. No wonder high post-harvest losses are easily noticeable in the markets and roads during the harvest periods. The issue compelled the government to act through establishing an orange juice processing plant in 2011 in Za-kpota district. This arouses farmers' enthusiasm. Hence, an increase in sweet oranges harvest areas has been recording since 2009 (FAO, 2018; Massokonon, 2015). But, this public citrus processing plant is still struggling to operate. The promotion of processing plants by private actors across the main citrus growing districts seems to be the right path to cope with the postharvest losses' issues. Besides, the direct exhibition of citrus fruits on the ground should be discouraged.

The storage and transport in plastic fruit crate and the promotion of post-harvest disease management methods like hot water or vapour treatment, UV light treatment, and biocontrol agents should be highly advised. Another radical but effective way to improve citrus shelf life is the use of post-harvest fungicides molecules such as Imazalil (IZ), thiabendazole (TBZ), sodium ortho-phenyl phenate (SOPP), fludioxonil (FLU), and pyrimethanil. Nevertheless, they might be dangerous for the population, as they are involved in public health issues, particularly in the Benin Republic, where most of the rural population populations have limited knowledge of their use and potential consequences.

\section{MAIN USES}

Citrus fruits are mainly consumed fresh or as processed juice in the Benin Republic. It is the third most consumed fruit after mango (Mangifera indica) and banana (Musa spp) (Tossou et al., 2012). Human health benefits from the crop fruit are well known in the country. Malaria, the primary cause of illness and death in the Benin Republic, is locally treated by a mixture of different plant cultivars, including citrus; prepared as decoction or infusion with water or fermented maize water (Hermans et al., 2004; Zinsou \& Cherifath, 2017). Indeed, the effect of Tahiti acid lime and Sour orange on the causal agent of malaria (Plasmodium falciparum) has been clinically proved (Addae-Kyereme et al., 2001; Weenen et al., 1990). Associated with Jute mallow (Corchorus olitorius), citrus cultivars are thought to treat malaria and typhoid fever (Adebo et al., 2018).

Peeled orange seeds are crushed under the teeth, and the juice swallowed; it would be a powerful deworming for children. Bath of water and limes juice is reported to relieve fever caused by children's exhaustion (Houéto et al., 2007). The same result would be obtained by a mixture of kerosene oil, palm oil, and lime juice used as a cream. The digestive power of orange juice and its richness in fresh enzymes, minerals, and vitamins are also much appreciated here, especially in convalescence. Muslims add orange to their diet during the month of Ramadan (Zadji, 2014) to break the fast in the evening after the prayer. Dry citrus peels are also burned for the insecticide properties of the essential oil that it contains.

\section{IMPORTANCE OF CITRUS INDUSTRY}

Alotta actors ranging from farmers to retailers, through agricultural workers, transporters, wholesalers, semi-wholesalers and exporters involves in citrus trade. It is a source of enormous income. Zadji (2014) by citing ESCiP-Benin (Ecological Sustainable Citrus Production in Benin) project reported that the average annual income per farmer was estimated at 1,437,293 CFA francs, 143, 070 CFA francs and 57,500 CFA francs for orange, mandarin, and lemon, respectively.

Moreover, in respect of the climates (monthly average rain, daily average temperature, daily length, relative humidity $(\mathrm{RH})$ ) and soils parameters ( $\mathrm{pH}$, altitude, structure, texture) of West African region, Benin Republic is most suitable for citrus cultivation compare to non-coastal West-African countries such as Niger, Mali, and BurkinaFaso. Beninese sweet oranges are exported to Niger and Togo and, sweet orange and Orlando tangelo to Nigeria (Akohoue et al., 2018; Gnimadi, 2008; Lokossou et al., 2009; Praloran, 1972). The creation of the value chain and prospects of new markets may add value to citrus fruits in the country. 


\section{MAIN CONSTRAINTS}

Citrus production was being challenged by increasing biotic and abiotic constraints around the world.

\section{Abiotic constraints}

Soil and fertilization

Citrus grows in a broad range of soils. However, it needs to be well-drained, fertile, well-aerated with a $\mathrm{pH}$ ranging from 6 to 6.5 , and good physical properties (clayey content of 10-40\%; no clayey, mottled or/and structural layers within the first meter of the soil surface; no rock or gravel layer, mottled clayey soil or/and sandy mottled layer in the first meter) (NDA, 2000).

Tropical ferruginous soils covered $80 \%$ of the Benin Republic (MEHU, 1993). Sensitive to erosion, they are characterized by an extreme deficiency in capillary water with non-solubilize phosphorus. Slightly ferrallitic soils of good agronomic quality on the southern-Benin's plateau extend over about $5 \%$ of the national land. Hydromorphic soils of valleys, basins, and alluvial plains cover 5 to $8 \%$ of the country. Vertisols of median depressions (Lama) covered about $5 \%$ of the country. They are clayey, thick and fertile. The central and northern Benin is generally covered by crude and undeveloped soils, and rocks.

Soil fertility was identified as one of the top ten constraints for citrus cultivation. In commercials orchards, smallholder farmers use to manage soil fertility with crop residues (Akohoue et al., 2018) and animal wastes. Some farmers mix chemical and organic fertilizer while others exclusively use Urea $(46 \% \mathrm{~N})$ or compound fertilizers derive from a diversion of those designed for cotton $\left(14 \mathrm{~N}-23 \mathrm{P}_{2} \mathrm{O}_{5}-14 \mathrm{~K}_{2} \mathrm{O}-5 \mathrm{~S}-1 \mathrm{BO}_{3}\right)$ and vegetable cultivation $\left(15 \mathrm{~N}-15 \mathrm{P}_{2} \mathrm{O}_{5}-15 \mathrm{~K}_{2} \mathrm{O}\right)$ due to the lack of specific mineral fertilizer of citrus in the country (Akohoue et al., 2018; Massokonon, 2015). Some magnesium and Zinc deficiency cases and, manganese excess have been reported on citrus trees across the southern part of the country (Cassin, 1974; Lokossou et al., 2009; Montagut, 1974).

The access to input, including specific citrus fertilizers, is the second principal limit of citrus cultivation in the Benin Republic (Akohoue et al., 2018). The development, introduction, and promotion of specific fertilizers for citrus in every single agro-ecological zone of the southern-Benin Republic are needed to boost citrus production.
Climate change

Climate change, which affects the entire country, may negatively affect citrus production in upcoming years. Yet, Akohoue et al. (2018) pointed out climate variability as the third most important crucial constraint for citrus cultivation in the Benin Republic. It may directly or/ and indirectly affect citrus phenology, and the crop interactions of the crop with various pests, pathogens, and soil microbial communities.

\section{Temperature}

Between 1961 and 2010, an annual temperature variance ranging from -0.6 to $+0.8^{\circ} \mathrm{C}$ was recorded in the Benin Republic. An increase up to $3.27^{\circ} \mathrm{C}$ compared to the mean temperature of $1971-2000$ is forecasted for the end of this century (MEHU, 2011). As tropical plant cultivars have a narrow temperature growth range, they are more sensitive to temperature change. Citrus is particularly vulnerable (Rosenzweig et al., 1996).

Navel trees, for instance, tend to set smaller crops in the warmer parts of South-Africa (NDA, 2000). During the early first fruit set period or bloom, warm temperatures cause fruit abscission. (Moss, 1969; Ono et al., 1988; Reuther, 1973). Citrus fruit quality (development of sugars and colour) is also greatly influenced by temperature; with a decrease of tree-storage time coupled with an increase of rind re-greening under high temperature (Mechlia \& Carroll, 1989; Reuther, 1973).

Warm is generally associated with an increase in disease development risk for most pathosystems (DesprezLoustau et al., 2007). Citrus is favourable host of seven (7) viroids [Citrus exocortis viroid (CEVd, genus Pospiviroid), Citrus bent leaf viroid (CBLVd, genus Apscaviroid), Citrus bark cracking viroid (CBCVd, genus Cocadviroid), Citrus dwarfing viroid (CDVd, genus Apscaviroid), Citrus viroid $\mathrm{V}(\mathrm{CVd}-\mathrm{V}$, genus Apscaviroid), Citrus viroid VI (CVd-VI, genus Apscaviroid), Citrus cachexia viroid (CCaVd, Hostuviroid)] (Lefkowitz et al., 2018) and a quite number of viruses.

Warmer climate boosts viroid disease severity and influences the host's primary infection, the spread of the infection within the host, the spread of the infection within the host and/or the horizontal transmission of viruses to new hosts by vectors (Elad \& Pertot, 2014; Singh, 1983). By simulating the effect of climate change on water requirement of citrus crop in major citrus growing areas of 
the globe, Fares et al. (2017) showed that under a carbon dioxide concentration of $360 \mathrm{ppm}$, an increase of $1^{\circ} \mathrm{C}$ of atmospheric temperature increases irrigation requirement by $8 \%$ and evapotranspiration by $4-5 \%$. High temperatures coupled with high moisture promote and initiate disease development, along with the germination and reproduction of varied diseases' fungal spores (Agrios, 2005).

\section{Carbon dioxide $\left(\mathrm{CO}_{2}\right)$}

The atmospheric carbon dioxide, which increased by $30 \%$ last years, is the major greenhouse gas (GHG) contributing to global climate change (Chakraborty et al., 2000). The high level of carbon dioxide in the atmosphere increases photosynthesis, leaf area, plant height, total biomass, crop yield, sugar and starch content, evapotranspiration and irrigation requirement, water-use efficiency, growth, and yield (Eastburn et al., 2011; Fares et al., 2017; Heagle et al., 1979) of C3 plants including citrus. This results in the change in plant architecture and the development of larger plant organs (Pritchard et al., 1999). Many pests and foliar pathogens (Alternaria alternata pv. citri, Phytophtora citrophthora, etc) can take advantage of the more humid microclimate of this denser plant growth and the higher availability of host tissue by increasing their reproduction rates (Chakraborty \& Datta, 2003; Plazek et al., 2001) and infection. Knowing that the fossil carbon dioxide emissions increased from 414.66 kilotons in 1990 to 7,096.94 kilotons in 2017 in the Benin Republic (Muntean et al., 2018), citrus production is expected to be affected.

\section{Rainfall}

In the Benin Republic the effects of climate change on rainfall patterns are portrayed through a high concentration of rainfall over a short period leading to a flood (1962, 1968, 1988, 1997, 1998 and 2010), a sudden interruption of rainfall during the rainy season (MEHU, 2011) and extension of the drying season (drought of 1977 and 1983). Both excessive watering (flood and drought) engender fruit splitting (Sato, 2015). This physiological disorder was reported by Massokonon (2015) on sweet orange in Za-kpota district in the central Benin Republic. Flood causes the asphyxiation, slow growth or death of citrus roots; leading to the cessation of water and nutrient uptake and stomatal closure (Hardy et al., 2012). Citrus canker's occurrence rate may rise due to the recent and upcoming massive rainfalls.
In the last years, the Benin Republic experienced a decrease in the monthly rainfall. A decrease up to $21 \%$ during the month of march and april has been recorded in the southern districts (MEHU, 2011). The scarcity of water in every single stage of the citrus crop greatly diminishes the citrus fruit quality and yield (Panigrahi \& Srivastava, 2017). Water stress is also known to cause stomatal closure and photosynthesis reduction; inhibition of leaf growth and, shoot architecture changes, and the root/shoot ratio (Elad \& Pertot, 2014). It was thought to cause citrus tree drying and premature fruit dropping in Benin Republic (Akohoue et al., 2018). Drip irrigation and mulching may help to mitigate the effects of drought in citrus orchards.

\section{Pruning}

It is a common task involving in removing unwanted, unhealthy, and dead branches on fruit crops. When it is well done, pruning helps controlling plant size and shape, and then enhances plants exposure to sunlight, which maximizes flowering. Pruning, topping, and hedging have been reported to increase fruit size, improve fruit colour, peel characteristics and the shelf life of fruit destined for the fresh market (Tucker et al., 1994).

In the Benin Republic, citrus plants are not pruned. This drive to fruits harvesting difficulties, inadequate fruit size, fungi development, mosses, and lichens on the plants (Akohoue et al., 2018; Lokossou et al., 2009). Because the pruning with traditional tools such as machete requires labours and is energy and time-consuming, the promotion electric pole saw and electric pruner in citrus growing area may help farmers.

\section{Biotic constraints}

Worldwide, citrus is affected by fungi, bacteria, virus, viroid, spiroplasma, phytoplasma, nematode, snail, mollusc, insect, and mite (El-Otmani et al., 2011; Ollitrault \& Navarro, 2012). Pests and diseases have been identified as the first constraint for citrus cultivation in Benin Republic (Akohoue et al., 2018).

Pests

Citrus leaf miner (Phyllocnistis citrella), grasshopper (Zonocerus variegatus), green tree ant (Oecophylla 
smaragdina), cottony cushion scale (Icerya purchasi), citrus rust mite (Phyllocoptruta oleivora (Ashmead)), fruit flies, caterpillars, biting butterflies, and termites are reported to cause damages to citrus trees in the country (Cassin, 1974; Lokossou et al., 2009; Montagut, 1974; Praloran, 1972; Zadji, 2014).

Zadji (2014) by citing ESCiP-Benin project reported that termites are probably the most devastating among pests, making tunnels through citrus stems, weakening plants and causing losses ranging from 25 to $50 \%$; the most frequent termites found in citrus orchards in the southernBenin Republic are Trinervitermes occidentalis (Sjöstedt), Amitermes guineensis (Sjöstedt), Macrotermes bellicosus (Smeathman), and Ancistrotermes crucifer (Sjöstedt). They are mostly managed with chemical pesticides (fipronil, deltametrin, dimethoate, and fenitrothion) (Zadji, 2014). Likewise, successful biocontrol of Macrotermes bellicosus (Smeathman), the most damaging termite in citriculture in the southern-Benin Republic was performed using Hymenocallis sonorensis and $H$. indica through the ESCiP-Benin project.

Bactrocera. invadens, B. cucurbitae, Ceratitis fasciventris (Bezzi), C. ditissima (Munro), C. anonae Graham, and Dacus punctatifrons Karsch are the main insects infecting citrus fruits in southern-Benin. B. invadens is the major treat with $20 \%$ of infestation rate and $35 \%$ incidence mainly on Ortatique tangor, tangelo, and sweet oranges (Vayssieres et al., 2011).

Citrus rust mite (CRM), Phyllocoptruta oleivora (Ashmead), infects citrus plants and causes fruit rind rusting resulting in loss of fruit quality making them unfit for export (Praloran, 1972; Vogel, 1972).

Biting butterflies feed on citrus tangelo, especially in the southern Benin Republic, where they cause significant losses on Dancy tangerine (Cassin, 1974; Praloran, 1972). Biting butterflies destroy the first harvested fruits (marchjuly) and cause massive damage to the second harvested (november-january) of Marsh grapefruit (Cassin, 1974; Montagut, 1974). Cottony cushion scale depreciates fruit quality by biting them and secreting honeydew, the medium on which Sooty mould grows (Lokossou et al., 2009).

Lambda 25 (Lambdacyhalothrine15g/1+Acétamipride10g/l), Laser 480SC (Spinosad 480g/l), Pacha 25EC (Acetamipride $10 \mathrm{~g} / 1+$ Lambdacyhalotrine $15 \mathrm{~g} / 1$ ) and Lambda Finner 2.5 EC (Lambdacyhalothrine $25 \mathrm{~g} / \mathrm{l}$ ) are commonly used to control citrus pests including fruit flies. It will be better to introduce various methods to fulfil the Integrated Pest Management (IPM) in the Beninese citrus industry.
The promotion of power sprayer machines and specific pesticides should also commit to the IPM.

\section{Diseases}

Citrus tristeza virus (CTV), the most destructive virus in citriculture was reported to infect several citrus cultivars in all regions except the extreme North-Benin Republic in the early modern citrus cultivation stage (Brun, 1971; Cassin 1974; Montagut, 1974; Vogel, 1972, 1975). In 1972, one or a combination of severe CTV symptoms (Stem pitting, inverse pitting, vein clearing, and quick decline) were observed on Eureka lemon, Common mandarin, Washington Navel sweet orange, Wekiwa tangelo, and Marsh grapefruit grafted ether on sour orange and Alemow. Tahiti acid lime, Bergamot, grapefruit, limequat (C. aurantifolia x Fortunella spp.) seedlings were also reported to be infected. However, bodjecali, a local lime, seemed to be resistant and Limequat tolerant to CTV (Cassin, 1974). Most recently, Toxoptora auranti, one the most efficient vector of CTV, has been reported feeding in large scales on citrus trees. (Lokossou et al., 2009; Massokonon, 2015).

During the first 3-6 years of cultivation in the Benin Republic, citrus is frequently intercropped with cassava, maize, cowpeas, cotton, peanuts, soybeans (Akohoue et al., 2018; Gnimadi, 2008; Lokossou et al., 2009; Massokonon, 2015). This association is particularly perilous in the case of cotton and corn, as citrus is an alternative host of cotton aphid (Aphis gossypii Glover) and green peach aphid (Myzus persicae), other important vectors of CTV.

Exocortis is another significant citrus disease caused by CEVd. It is a graft transmissible and mechanical propagated plant pathogen. CEVd has been reported infecting citrus cultivars grafted on Citrange, Rough lemon and Rangpur lime which exhibited bark cracking and vertical scaling on the rootstock (Vogel, 1972). The disease symptoms were later observed on Bergamot, Duncan grapefruit, and Washington Navel sweet orange (Cassin, 1974; Vogel, 1975). As CEVd-free Washington Navel sweet orange was imported from France, the infection was thought to occur at Toué /Bohicon (Vogel, 1975). More recently, Lokossou et al. (2009) observed CEVd symptoms on sweet orange grafted on Rangpur lime in the Ouémé department (South-East Benin) (Figure 2). Land clearing, orchards weeding, holes digging and hoeing are carried out with traditional tools such as hoe and machete. In this manner citrus intercropping with vegetables like tomato 
may play an active role in CEVd epidemiology as both crops are hosts to the pathogen.

Cachexia disease caused by Citrus cachexia viroid on common mandarin grafted on Rangpur lime at Djassin near Porto-Novo; psorosis gummosis caused by Citrus psorosis virus (CPsV) on orange at Bohicon and stubborn disease caused by Spiroplasma citri on Washington Navel sweet orange at Bohicon were also reported (Vogel, 1972, 1975).

Fungal diseases are very prevalent in citrus orchards and nurseries. High rainfall and relative humidity $(\mathrm{RH})$, the richness of soils in clay and fine particles, and sensitive rootstocks are the leading causes. A fertilization method consisting of gathering plants debris at the foot of citrus plants increases the moisture and promotes the development of soil-borne fungi, especially in the rainy season. Then, gummosis caused by Phytophtora citrophthora and Diplodia natalensis were reported on citrus in the Southern-East and Center-Benin respectively (Praloran, 1972). Alternaria alternata pv. citri was also reported infecting grapefruit trees in Atlantique department and Rough lemon nurseries in the Couffo department (Figure 2). The greasy spot caused by Mycosphaerella citri, Citrus scab caused by Elsinoe fawcetti and black mildew caused by Meliola citricola were also reported (Lokossou et al., 2009). Preventive painting of citrus trees' bole with a Bordeaux mixture could help to reduce the incidence and severity of Phytophthora spp. Also, the spraying of Bordeaux mixture, copper hydroxide, copper sulphate, potassium phosphate and neem kernel suspension would contribute to the management of leafborne fungal diseases.

Worldwide, physiological disorders, physical damages, fruit senescence, and diseases cause post-harvest losses on citrus fruits. Fungal pathogens are the leading cause. Based on the initial infection source, citrus post-harvest diseases are split into two groups as described by Strano et al (2017) :

- Preharvest infections that include Alternaria rot (Alternaria spp.), Brown rot (Phytophthora spp.), Grey mould (Botrytis cinerea Pers.), Anthracnose (Colletotrichum gloeosporioides Penz.), and Stem-end rot (Diplodia natalensis Pole-Evan, Phomopsis citri Fawcet);

- post-harvest infections, including Sour rot (Geotrichum candidum Link), Blue mould (P. italicum Weh.), and Green mould (Penicillium digitatum Sacc.).

Citrus grown in humid and warm areas have more diseases than those grown in cooler or drier climates. The fact seems to be evident in all citrus growing and selling areas of the Benin Republic, but research-based papers still lack.

As stated upper, the citrus crop is highly harmed by several diseases. Their management requires the mapping and characterization of pathogens involved in citrus diseases in the Benin Republic; the setting up of citrus certification program and production of pathogens-free plant materials; the setting up of quarantine system; the screening of climate smart and diseases tolerant or resistant citrus rootstocks in different agro-ecological zones of the country; the establishment of renewal program of old citrus orchards through the promotion of new rootstocks; the training of farmers and nursery workers on simple, effective, environment and consumer friendly citrus sanitation methods.

\section{CONCLUSION}

The Benin Republic owns the right climate and soils of good quality for citrus production. This may play an essential socio-economical role by committing to a nutritional gaps fulfillment in the Benin Republic as well as in the West-African region where people rely almost exclusively on staple crops. Unfortunately, pests, diseases and, lack of technical knowledge and policies seriously harm the crop. The forthwith implementation of the proposed solutions is foreseen to reverse the long time and negative citrus' trends into positive.

\section{ACKNOWLEDGEMENTS}

The authors are grateful to Abdoul Razack SARE, Flavien SHIMIRA, and reviewers for their critical reading of the manuscript. The authors are thankful to Agritrop for providing part of the articles quoted in this document.

\section{REFERENCES}

Addae-Kyereme, J., Croft, S. L., Kendrick, H., \& Wright, C. W. (2001). Antiplasmodial activities of some Ghanaian plants traditionally used for fever/malaria treatment and of some alkaloids isolated from Pleiocarpa mutica; in vivo antimalarial activity of pleiocarpine. Journal of Ethnopharmacology, 76(1), 99-103. http://dx.doi. org/10.1016/S0378-8741(01)00212-4. 
Adebo, H. O., Ahoton, L. E., Quenum, F. J. B., AdoukonouSagbadja, H., Bello, D. O., \& Chrysostome, C. A. A. M. (2018). Ethnobotanical knowledge of Jute (Corchorus olitorius L.) in Benin. European Journal of Medicinal Plants, 26(1), 1-11. http://dx.doi.org/10.9734/EJMP/2018/43897.

Agrios, G. N. (2005). Plant pathology. 5th ed. London: Elsevier.

Akohoue, F., Segnon, A. C., \& Achigan-Dako, E. G. (2018). Diversity in smallholder citrus orchards and cultivation bottlenecks: research avenues for improved production in Benin, West-Africa. Experimental Agriculture, 54(5), 641-654. http://dx.doi.org/10.1017/S001447971700028X.

Boko, M. (1992). Saisons et types de temps au Benin: analyse objective et perceptions populaires. L'Espace Geographique, 21(4), 321-332. http://dx.doi.org/10.3406/ spgeo.1992.3106.

Brun, J. (1971). Rapport sur la mission effectuée au Cameroun du 24-02 au 11-03-71 et au Dahomey du 11-03 au 15-03-71. Paris: GERDAT-IFAC.

Cassin, J. (1974) Résultats préliminaires de l'étude du comportement de certaines variétés d'agrumes introduites au Dahomey, en Côte d'Ivoire, au Cameroun, à Madagascar et à la Réunion. Paris: GERDAT-IFAC, 36p.

Chakraborty, S., \& Datta, S. (2003). How will plant pathogens adapt to host plant resistance at elevated $\mathrm{CO} 2$ under a changing climate? The New Phytologist, 159(3), 733-742. http://dx.doi.org/10.1046/j.1469-8137.2003.00842.x.

Chakraborty, S., Tiedemann, A. V., \& Teng, P. S. (2000). Climate change: potential impact on plant diseases. Environmental Pollution, 108(3), 317-326. http://dx.doi. org/10.1016/S0269-7491(99)00210-9.

Cirad. (2016). Citrus cultivation (pp. 57-58). Frui Trop.

Desprez-Loustau, M. L., Robin, C., Reynaud, G., Déqué, M., Badeau, V., Piou, D., Husson, C., \& Marçais, B. (2007). Simulating the effects of a climate-change scenario on the geographical range and activity of forest-pathogenic fungi. Canadian Journal of Plant Pathology, 29(2), 101120. http://dx.doi.org/10.1080/07060660709507447.

Eastburn, D. M., McElrone, A. J., \& Bilgin, D. D. (2011). Influence of atmospheric and climatic change on plantpathogen interactions. Plant Pathology, 60(1), 54-69. http://dx.doi.org/10.1111/j.1365-3059.2010.02402.x.

Elad, Y., \& Pertot, I. (2014). Climate change impact on plant pathogens and plant diseases. Journal of Crop
Improvement, 28(1), 99-139. http://dx.doi.org/10.1080/ 15427528.2014 .865412 .

El-Otmani, M., Ait-Oubahou, A., \& Zacarías, L. (2011). Citrus spp: orange, mandarin, tangerine, clementine, grapefruit, pomelo, lemon and lime. In E. M. Yahia (Ed.), Postharvest biology and technology of tropical and subtropical fruits (pp. 437-516). Sawston, UK: Woodhead Publishing. http://dx.doi.org/10.1533/9780857092762.437.

Fares, A., Bayabil, H. K., Zekri, M., Mattos-Jr, D., \& Awal, R. (2017). Potential climate change impacts on citrus water requirement across major producing areas in the world. Journal of Water and Climate Change, 8(4), 576-592. http://dx.doi.org/10.2166/wcc.2017.182.

Food and Agriculture Organization of the United Nations - FAO. (2018). Food and Agriculture Organization of the United Nations database (FAOSTAT). Rome: FAO. Retrieved in 2020, February 21, from http://www.fao. org/faostat/

Gnimadi, A. (2008). Etude pour l'indentification des filières agroindustrielles prioritaires (Benin). Ouagadougou: UEMOA.

Hardy, S., Barkley, P., Creek, A., \& Donova, N. (2012) Agriculture New South Wale. Retrieved in 2020, February 4, from https://www.dpi.nsw.gov.au/_data/assets/ pdf_file/0013/430222/Impacts-and-management-offlooding-and-waterlogging-in-citrus-orchards.pdf

Heagle, A. S., Spencer, S., \& Letchworth, M. B. (1979). Yield response of winter wheat to chronic doses of ozone. Canadian Journal of Botany, 57(19), 1999-2005. http:// dx.doi.org/10.1139/b79-250.

Hermans, M., Akoègninou, A., \& Van der Maesen, L. J. G. (2004). Medicinal plants used to treat malaria in southern Benin. Economic Botany, 58(sp1), S239-S252. http://dx.doi.org/10.1663/0013-0001(2004)58[S239:MP UTTM]2.0.CO;2.

Houéto, D., Hounsa, A., D'Hoore, W., Deccache, A., $\&$ Ouendo, E. M. (2007). Fièvre chez l'enfant en zone d'endémie palustre au Bénin: analyse qualitative des facteurs associés au recours aux soins. Santé Publique, 19(5), 363-372. http://dx.doi.org/10.3917/spub.075.0363.

Krueger, R. R. (2003). Encyclopedia of food and culture. Retrieved in 2019, March 9, from https://www.encyclopedia. $\mathrm{com} /$ food/encyclopedias-almanacs-transcripts-and-maps/ citrus-fruit 
Lefkowitz, E. J., Dempsey, D. M., Hendrickson, R. C., Orton, R. J., Siddell, S. G., \& Smith, D. B. (2018). Virus taxonomy: the database of the International Committee on Taxonomy of Viruses (ICTV). Nucleic Acids Research, 46(D1), D708-D717. http://dx.doi.org/10.1093/nar/gkx932.

Levey, Z. (2008). Israel's exit from Africa, 1973: the road to diplomatic isolation. British Journal of Middle Eastern Studies, 35(2), 205-226. http://dx.doi. org/10.1080/13530190802180621.

Liu, Y., Heying, E., \& Tanumihardjo, S. A. (2012). History, global distribution, and nutritional importance of citrus fruits. Comprehensive Reviews in Food Science and Food Safety, 11(6), 530-545. http://dx.doi. org/10.1111/j.1541-4337.2012.00201.x.

Lokossou, B., Tossou, C., Varnier, C., \& Ollitrault, P. (2009). Mission d'évaluation de l'agrumiculture au Bénin. Cotonou: INRAB.

Massokonon, M. J. B. (2015). Impact de l'implantation de l'usine de transformation d'orange en jus d'orange sur la production et la commercialisation d'orange à Za-Kpota: etude diagnostique (Mémoire de licence). Faculté des Sciences Agronomiques, Université d'Abomey-Calavi, Abomey-Calavi, Républiaue du Bénin.

Mechlia, N. B., \& Carroll, J. J. (1989). Agroclimatic modeling for the simulation of phenology, yield and quality of crop production. International Journal of Biometeorology, 33(1), 36-51. http://dx.doi.org/10.1007/ BF01045896.

MEHU (Ministère de l'Environnement, de l'Habitat et de l'Urbanisme). (1993). Plan d'action environnemental du Bénin. Cotonou: MEHU.

MEHU (Ministère de l'Environnement, de l'Habitat et de l'Urbanisme )(2011). Deuxieme communication nationale de la republique du Bénin sur les changements climatiques. Cotonou: MEHU.

Montagut, G. (1974). Note sur les variétés d'agrumes importées au Dahomey. Paris: GERDAT-IFAC.

Moss, G. I. (1969). Influence of temperature and photoperiod on flower induction and inflorescence development in sweet orange (Citrus Sinensis L. Osbeck). Journal of Horticultural Science, 44(4), 311-320. http://dx.doi.org /10.1080/00221589.1969.11514314.

Muntean, M., Guizzardi, D., Schaaf, E., Crippa, M., Solazzo, E., \& Olivier, J. G. J. (2018). Fossil CO2 emissions of all world countries-2018 report (241 pp.). Luxembourg:
Publications Office of the European Union. http://dx.doi. org/10.2760/30158.

National Department of Agriculture-South Africa - NDA. (2000). Cultivating CITRUS. Retrieved in 2019, September 25, from https://www.nda.agric.za/docs/Citrus/citrus.htm

Ollitrault, P., \& Navarro, L. (2012). Citrus. In M. L. Badenes, \& D. H. Byrne (Eds.), Fruit breeding (pp. 623-662). Boston: Springer. http://dx.doi.org/10.1007/978-1-4419-0763-9_16.

Ono, S., Hirose, K., Takahara, T., Iwagaki, I., \& Yoshinaga, K. (1988). Studies on physiological fruit drop in mid and late maturing citrus cultivars: 1 . Inter-cultivar difference and relationship between physiological fruit drop and ecological factors. Bulletin of the Fruit Tree Research Station Series D, 10, 47-68.

Panigrahi, P., \& Srivastava, A. K. (2017). Water and nutrient management effects on water use and yield of drip irrigated citrus in vertisol under a sub-humid region. Journal of Integrative Agriculture, 16(5), 1184-1194. http://dx.doi.org/10.1016/S2095-3119(16)61500-9.

Plazek, A., Hura, K., Rapacz, M., \& Zur, I. (2001). The influence of ozone fumigation on metabolic efficiency and plant resistance to fungal pathogens. Journal of Applied Botany, 75(1), 8-13.

Praloran, J. C. (1972). L'agrumiculture dahoméenne: situation actuelle, amélioration et développement. Paris: GERDAT-IFAC.

Pritchard, S. G., Rogers, H. H., Prior, S. A., \& Peterson, C. M. (1999). Elevated CO2 and plant structure: a review. Global Change Biology, 5(7), 807-837. http://dx.doi. org/10.1046/j.1365-2486.1999.00268.x.

Retiz, H. J. (1968). How much water do Florida citrus trees use? Citrus Industry, 49(10), 4-6.

Reuther, W. (1973). Limate and citrus behavior. In W. Reuther(Ed.), The citrus industry (Vol III, pp. 280-337). California: University of California.

Rosenzweig, C., Phillips, J., Goldberg, R., Carroll, J., \& Hodges, T. (1996). Potential impacts of climate change on citrus and potato production in the US. Agricultural Systems, 52(4), 455-479. http://dx.doi. org/10.1016/0308-521X(95)00059-E.

Sato, K. (2015). Influence of drought and high temperature on citrus. In Y. Kanayama, \& A. Kochetov (Eds.), Abiotic stress biology in horticultural plants (pp. 77-86). Tokyo: Springer Japan. http://dx.doi.org/10.1007/978-4-431-55251-2_6. 
Singh, R. P. (1983). Viroids and their potential danger to potatoes in hot climates. Canadian Plant Disease Survey, 63(1), 13-18.

Strano, M. C., Altieri, G., Admane, N., Genovese, F., \& Di Renzo, G. C. (2017). Advance in citrus postharvest management: diseases, cold storage and quality evaluation. In H. Gill, \& H. Garg (Eds.), Citrus pathology (pp. 139159). Rijeka: Intech. http://dx.doi.org/10.5772/66518.

Tossou, C. C., Floquet, A. B., \& Sinsin, B. A. (2012). Relation entre la production et la consommation des fruits cultivés sur le plateau d'Allada au sud du Benin. Fruits, 67(1), 3-12. http://dx.doi.org/10.1051/fruits/2011061.

Tucker, D. P. H., Wheaton, T. A., \& Muraro, R. P. (1994). Florida cooperative extension service. University of Florida. Retrieved in 2019, May 9, from https://counties. agrilife.org/harris/files/2011/05/Citrus-Pruning.pdf

Turner, T., \& Burri, B. (2013). Potential nutritional benefits of current citrus consumption. Agriculture, 3(1), 170-187.

Vayssieres, J., Adandonon, A., Sinzogan, A., \& Korie, S. (2011). Diversity of fruit fly species (Diptera: Tephritidae) associated with citrus crops (Rutaceae) in southern Benin in 2008-2009. International Journal of Biological and Chemical Sciences, 4(6), 1881-1897. http://dx.doi. org/10.4314/ijbcs.v4i6.64966.
Vogel, R. (1972). Compte-rendu de mission au Dahomey du 16 au 21 janvier 1972: problèmes phytosanitaires posés à l'agrumiculture dahoméenne (11 pp.). San Giuliano: GERDAT-IFAC/INRA.

Vogel, R. (1975). Compte-rendu de mission au Dahomey du 19 au 25 avril 1975: etat phytosanitaire des agrumes dahoméens (6 pp.). San Giuliano: GERDAT-IFAC/INRA.

Weenen, H., Nkunya, M. H. H., Bray, D. L., Mwasumbi, L. B., Kinabo, L. S., \& Kilimali, V. (1990). Antimalarial activity of tanzanian medicinal plants. Planta Medica, 56(4), 368-370. http://dx.doi.org/10.1055/s-2006-960984.

Zadji, L. D. V. (2014). Entomopathogenic nematodes as potential control agents of termites in citrus in Benin (Ph.D. thesis). University of Ghent, Belgium.

Zinsou, C., \& Cherifath, A. B. (2017). The malaria testing and treatment landscape in Benin. Malaria Journal, 16(1), 174. http://dx.doi.org/10.1186/s12936-017-1808-x.

Received: February 22, 2020 Accepted: August 10, 2020

How to cite: Afloukou, F., Zinsou, V., \& Onelge, N. (2020). Citrus in Benin Republic: past, present, and future challenges. Citrus Research \& Technology, 41, e1060. https://doi.org/10.4322/crt.20820 